\title{
Assessment of molluscicidal activity of essential oils from five Azorean plants against Radix peregra (Müller, 1774)
}

\author{
Tânia Teixeira ${ }^{\mathrm{a}, *}$, José Silvino Rosa ${ }^{\mathrm{a}}$, Nuno Rainha ${ }^{\mathrm{b}}$, José Baptista ${ }^{\mathrm{b}}$, Armindo Rodrigues ${ }^{\mathrm{b}, \mathrm{c}}$ \\ ${ }^{a}$ CIBIO - Research Center in Biodiversity and Genetic Resources, Azores, Department of Biology, University of Azores, $9501-801$ Ponta Delgada, Portugal \\ ${ }^{\mathrm{b}}$ Research Center of Natural Resources (CIRN), Department of Biology, University of Azores, 9501-801 Ponta Delgada, Portugal \\ ${ }^{c}$ Centre of Volcanology and Geological Risks Assessment (CVARG), University of Azores, 9501-801 Ponta Delgada, Portugal
}

\section{A R T I C L E I N F O}

\section{Article history:}

Received 4 April 2011

Received in revised form 10 November 2011

Accepted 11 November 2011

Available online 7 December 2011

\section{Keywords:}

Azorean plants

Essential oils

Molluscicidal activity

Ovicidal activity

Radix peregra

\begin{abstract}
A B S T R A C T
The molluscicidal activity of essential oils from two endemic (Juniperus brevifolia; Laurus azorica) and three introduced (Hedychium gardnerianum; Pittosporum undulatum; Psidium cattleianum) Azorean plants against the snail Radix peregra was studied under laboratory conditions. Essential oils from leaves of $H$. gardnerianum, L. azorica and J. brevifolia presented promising molluscicidal activity on both adults and juveniles stages of $R$. peregra. The molluscicidal activity of these essential oils was found to be both time and concentration dependent. Lethal concentrations $\left(\mathrm{LC}_{50}\right)$ varied between 15.4 ( $L$. azorica) and $44.6 \mathrm{ppm}$ (H. gardnerianum) for juveniles and from 45.3 (H. gardnerianum) to $54.6 \mathrm{ppm}$ (J. brevifolia) for $R$. peregra adults. Ovicidal effect, calculated as percentage of egg hatching, at $100 \mathrm{ppm}$ concentration, was observed in essential oils from $P$. undulatum flowers (4.2\% of hatching) and leaves of $H$. gardnerianum (4.9\%), L. azorica (7.4\%) and J. brevifolia (17.7\%). The present study is the first attempt to assess the molluscicidal potential of some Azorean plants essential oils against a Lymnaeidae snail. In fact, the $H$. gardnerianum, L. azorica and J. brevifolia can offer natural alternative tools for the control of $R$. peregra population, but more research is needed in order to determine the mode of action of these oils and determine the side effects on the ecosystem where this freshwater snail occurs.
\end{abstract}

(c) 2011 Elsevier Ltd. All rights reserved.

\section{Introduction}

Fascioliasis has a worldwide distribution, being found in the subtropical and tropical regions of the world, including Latin America, USA, UK, Ireland, Europe, Middle East, Asia and Africa. Even though, the intermediate host belongs, normally, to the Lymnaeidae family, Fasciola hepatica reveals a high ability to parasite a large host diversity, e.g. Lymnaea humilis, Lymnaea bulimoides, Lymnaea cubensis, Lymnaea viatrix and Lymnaea neotropica, Lymnaea columella (in Latin America), and Lymnaea bulimoides (in North America) (Cruz-Mendoza et al., 2004; Bargues et al., 2007; Lima et al., 2009). In Europe (including Azores) the common liver fluke, $F$. hepatica, its a parasite whose primary intermediate host is the freshwater snail Galba (=Lymnaea) truncatula Müller, 1774.

In the Azores, the disease was first detected in 1962 in São Miguel Island, but since 1983 the Veterinary Services of the island, based on the number of animals slaughtered in controlled municipal slaughterhouse, confirmed the growth of disease.

It subsequent years, studies of Mendonça (1987) and Furtado and Cunha (2002), based on data from Ponta Delgada's slaughter-

\footnotetext{
* Corresponding author. Tel.: +351296 650 101; fax: +351296650100.

E-mail address: tanny_lx@hotmail.com (T. Teixeira).
}

house, refer an average infection of 7.4 and $7.6 \%$ in 1983 and 1998 , respectively. In 2009 , it decreases to $2.58 \%$ (unpublished data).

The most effective method of eradication of fascioliasis is through the use of fasciolicide of easy application that no let residues in meat and milk, or through control of its intermediate host (Moens, 1982). On this last system the combination of prophylactic and structured methods on the host, through integrated control processes (mechanical, environmental, biological and chemical) could be the most effective approach. In Azores, several studies have addressed the distribution of G. truncatula in São Miguel Island (Backhuys, 1975; Mendonça, 1989a; Martins, 1991) as well as their control, both biological and ecological measures (Cunha, 1993), chemical and via the molluscicidal activity of floral species (Mendonça, 1989b).

The investigation of the molluscicidal properties of plants has recently been greatly expanded, with more than 1400 species studied thus far. Plant extracts have been used to control the snail population with the advantage that, besides being less toxic in nature, they can be degraded faster than the synthetic molluscicides that have also high cost, possible build up of snail resistance, and toxicity in nontarget organisms (Jaiswal and Singh, 2008; Radwan et al., 2008). Many plant products have been found to have a high molluscicidal potential (Singh et al., 1996a, 2006; Lahlou and Berrada, 
2001; Singh and Singh, 2005; Silva et al., 2006; Adenusi and Odaibo, 2008; El-Kamali et al., 2010; Kumar et al., 2010; Larhsini et al., 2010; Upadhyay and Singh, 2011).

In the Azores there are approximately 1000 vascular plant species. These plants are either part of the primitive vegetation in which 72 species are endemic, or have been recently introduced. Some of the plants, which were introduced for cultivation or ornamental purposes, are now naturalized and are spreading outside of the locations where they were originally planted. This study is a fraction of a larger project to investigate new environment-oriented tools to control trematode vectors in the Azores.

Particularly, this study focuses in the molluscicidal and ovicidal activity of essential oils from two Azorean endemic and three introduced plants against $R$. peregra, and thus a potential intermediate host for $F$. hepatica.

\section{Materials and methods}

\subsection{Plant material and distillation of the essential oils}

Leaves of the Azorean endemic plants Juniperus brevifolia (Seub.) Antoine (Cupressaceae) and Laurus azorica (Seub.) Franco (Lauraceae) were collected in protected locations near Nordeste (São Miguel Island) during the Summer of 2008. Hedychium gardnerianum Sheppard ex Ker-Gawler (Zingiberaceae), also locally known as "conteira", was collected during the Summer of 2008, in Sete Cidades (São Miguel Island) and its leaves used for essential oil preparation. Leaves and flowers of Pittosporum undulatum Vent. (Pittosporaceae) were collected in the campus garden of the University of the Azores during the flowering period. Finally, Psidium cattleianum Sabine (Myrtaceae) fruits were purchase from a local producer near Ponta Delgada. After collection, each plant material was placed in plastic bags and immediately brought to the laboratory, where it was stored at $-20^{\circ} \mathrm{C}$. Specimens were identified by specialist from the Herbarium of Carlos Machado Museum in Ponta Delgada.

A minimum amount of $2 \mathrm{~kg}$ of fresh vegetal material was used for the preparation of essential oils. Essential oils were obtained from the different plant parts by hydrodistillation during $4 \mathrm{~h}$, using a modified Clevenger apparatus according to the method described by Medeiros et al. (2003). The stock solutions were dissolved in ethanol at the concentrations of $100 \mathrm{mg}$ essential oils per $\mathrm{mL}(\mathrm{w} / \mathrm{v})$.

\subsection{Animal material}

Adult snails of $R$. peregra $(1.34 \mathrm{~cm} \pm 0.20 \mathrm{~cm}$ in length) were collected locally from Furnas (São Miguel Island) during the months of April and May 2009. The snails were allowed to acclimatize under laboratory conditions for $72 \mathrm{~h}$ before experiments. Some snails, not used in the assay, were maintained in polyethylene aquariums $(35.7 \mathrm{~cm} \times 23.5 \mathrm{~cm} \times 13.4 \mathrm{~cm})$ containing $3 \mathrm{~L}$ of spring water (19 $\left.\pm 1^{\circ} \mathrm{C}, \mathrm{pH} 7.3-7.4\right)$, with air pumps working permanently. In order to prevent any contamination, three times per week the aquaria was cleaned, removing excrements and dead snails. Lettuce leaves (Lactuca sativa L.) were used as foodstuff. Laboratorybred cultures of adult snails were kept for reproduction to obtain eggs and juveniles. The egg masses were observed under the light microscope to ascertain and confirm initial viability and extent of egg embryonation. Only viable eggs were used for ovicidal experimentation. A second group of eggs were kept for hatching to obtain juvenile snails (48-96 h after eclosion) which were further assayed in the same conditions as the adults.

\subsection{Molluscicidal activity assay}

The molluscicidal activity of essential oil samples was evaluated according to the method described by Schall et al. (1998) against juveniles and adults of $R$. peregra. Ten juveniles or adult snails were randomly transferred into glass beakers and submerged in $50 \mathrm{~mL}$ of spring water containing oil sample ( $50 \mu \mathrm{L}$ of the stock solutions) at a final concentration of $100 \mathrm{ppm}$ concentration for $24 \mathrm{~h}$ and maintained at room temperature $\left(23 \pm 1^{\circ} \mathrm{C}\right)$ under natural lightdark photoperiod. The beakers were covered with a plastic film (with small holes to permit aeration) to prevent snails from falling out. None of the snails were fed during this period. At the end of the exposure period, the surviving snails were washed and rinsed in spring water to remove essential oil solution and transferred into new beakers containing an identical volume of spring water for a $24 \mathrm{~h}$ phase of recovery. During this period, they were fed with fresh lettuce leaves. Control experiments were executed similarly, and simultaneously as the treatments. At the end of the recovery period the snail's mortality was determined, and confirmed by absence of heartbeat (in juveniles) and lack of reaction by probing the snails with a needle to elicit typical withdrawal movements (in adults). Four replicates of 10 snails were used for both essential oil samples and controls in this single-dose screening assay.

\subsection{Determination of lethal concentration $\left(L C_{50}\right)$ and lethal time $\left(L T_{50}\right)$}

The essential oil samples, whose mortality was higher than $70 \%$, were tested at six different concentrations (juveniles: 10, 20, 30, 40, 45, 60 ppm; adults: 30, 40, 50, 60, 70, 80 ppm) under the same conditions described above. Four replicates of 10 snails per concentration were used for this assay and statistic parameters lethal concentration $\mathrm{LC}_{50}$ and $\mathrm{LC}_{90}$ were determined.

To investigate time/mortality relationship (after time of exposure), the adults snails were exposed during 4,8 and $16 \mathrm{~h}$ to the essential oil sample at $50 \mathrm{ppm}$ concentration (equivalent to the $\mathrm{LC}_{50}$ values), below the equal circumstances described above. Snail's mortality was assessed every $2 \mathrm{~h}$ until 90\% mortality was achieved. Each treatment was repeated three times using 10 snails.

\subsection{Assay for activity against egg masses}

To evaluate the ovicidal effect according to the method described by Adenusi and Odaibo (2008), R. peregra egg masses containing 35-40 eggs each (48-72 h old), were permanently exposed for $24 \mathrm{~h}$ to $100 \mathrm{ppm}$ essential oil solutions (dissolved in less than $5 \%$ ethanol). One egg mass per replicate with a total of three replications was used. After the exposure period, the egg masses were washed and rinsed several times in spring water to remove the sample solution and transferred to beakers for incubation until hatching. When the desired developmental time was reached, the egg masses were examined daily and the number of unhatched eggs was counted and the ovicidal activity calculated as percentage hatching. An embryo in an egg mass was considered dead if its cells became opaque or disaggregated or if unhatched at the end of the experiment.

Two sets of controls were used. One set of egg masses was placed in water and a second group dipped in ethanol $5 \%(\mathrm{v} / \mathrm{v})$ to determine the mortality derived from the solvent used to dissolve the essential oils solutions.

\subsection{Analysis data}

Single-concentration mortality and ovicidal data were subjected to an analysis of variance procedure after arcsine transformation. Means with significant variance and F-statistic were 
Table 1

Mortality (\%) of Radix peregra when exposed for 24 and $48 \mathrm{~h}$ at a concentration of $100 \mathrm{ppm}$ of essentials oils from Azorean plants.

\begin{tabular}{|c|c|c|c|c|c|}
\hline \multicolumn{2}{|c|}{ Essential oils (parts used) } & \multirow[t]{2}{*}{$n^{\mathrm{A}}$} & \multirow{2}{*}{$\begin{array}{l}\text { Juveniles } \\
24 \mathrm{~h}( \pm \mathrm{SEM})^{\mathrm{B}}\end{array}$} & \multicolumn{2}{|l|}{ Adults } \\
\hline & & & & $24 \mathrm{~h}( \pm \mathrm{SEM})^{\mathrm{B}}$ & $48 \mathrm{~h}( \pm \mathrm{SEM})^{\mathrm{B}}$ \\
\hline \multirow[t]{2}{*}{ Control } & Untreated & 40 & $0.0 \pm 0.00^{b}$ & $0.0 \pm 0.00^{\mathrm{b}}$ & $2.5 \pm 2.50^{\mathrm{c}}$ \\
\hline & Ethanol & 40 & $2.5 \pm 2.50^{\mathrm{b}}$ & $0.0 \pm 0.00^{\mathrm{b}}$ & $5.0 \pm 2.90^{c}$ \\
\hline \multirow[t]{2}{*}{ Endemic } & Juniperus brevifolia (leaves) & 40 & $100.0 \pm 0.00^{\mathrm{a}}$ & $97.5 \pm 2.50^{\mathrm{a}}$ & $100.0 \pm 0.00^{\mathrm{a}}$ \\
\hline & Laurus azorica (leaves) & 40 & $100.0 \pm 0.00^{\mathrm{a}}$ & $100.0 \pm 0.00^{\mathrm{a}}$ & $100.0 \pm 0.00^{\mathrm{a}}$ \\
\hline \multirow[t]{4}{*}{ Introduced } & Hedychium gardnerianum (leaves) & 40 & $100.0 \pm 0.00^{\mathrm{a}}$ & $97.5 \pm 5.00^{\mathrm{a}}$ & $100.0 \pm 0.00^{\mathrm{a}}$ \\
\hline & Pittosporum undulatum (flowers) & 40 & $100.0 \pm 0.00^{\mathrm{a}}$ & $10.0 \pm 0.00^{\mathrm{b}}$ & $10.0 \pm 0.00^{c}$ \\
\hline & Pittosporum undulatum (leaves) & 40 & $100.0 \pm 0.00^{\mathrm{a}}$ & $10.0 \pm 5.80^{\mathrm{b}, *}$ & $50.0 \pm 17.3^{b}$ \\
\hline & Psidium cattleianum (fruits) & 40 & $100.0 \pm 0.00^{\mathrm{a}}$ & $7.5 \pm 4.80^{\mathrm{b}, *}$ & $26.7 \pm 8.70^{\mathrm{b}}$ \\
\hline
\end{tabular}

\footnotetext{
A Number of snails test.

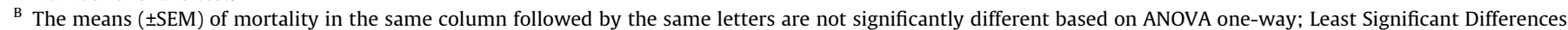
test for juveniles $(F$-test $=6.639, d f=31)$ and adults $(24 \mathrm{~h}: F$-test $=28.203, d f=31 ; 48 \mathrm{~h}$ : $F$-test $=126.786, d f=31)$.

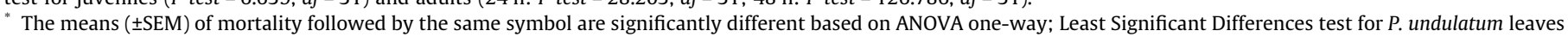
$(F-$ test $=8.271, d f=7)$ and $P$. cattleianum fruits $(F$-test $=7.146, d f=7)$.
}

separated by least significant differences test (LSD) using SPSS statistic package, software version 15.0 for Windows (SPSS, 2006).

Data from concentration-mortality and time-mortality assays from all replicates were used to calculate the $\mathrm{LC}_{50}$ (the concentration required to kill $50 \%$ of the snails), and $\mathrm{LT}_{50}$ (the exposure time required to obtain $50 \%$ mortality of snails) values, after correction to mortality data according to Abbot (1925). Then, this data were analyzed using the Statistical Analysis System (SAS, 1982). $\chi^{2}$ test was used to assess the goodness-of-fit of the model to the data (Finney, 1971). Differences among snails mortality were considered significant when the values from lethal concentration or lethal time failed to overlap the $95 \%$ confidence limits (CL).

\section{Results}

\subsection{Snail's susceptibility}

The toxicity of the essential oils from two endemic and three introduced plants common in Azorean archipelago against juveniles (2-3 d olds) and adult stages of $R$. peregra, are shown in Table 1 . The results showed that essential oils from leaves of $H$. gardnerianum, L. azorica and J. brevifolia were the most effective against juveniles and adults of $R$. peregra, followed by $P$. undulatum (leaves) and $P$. cattleianum (fruits). Essential oil from $P$. undulatum (flowers) was the least effective. The lethal effect showed on the juveniles of $R$. peregra was higher than the effect on adult snails. Actually, all samples exhibited considerable appetency for killing juvenile snails ( $100 \%$ mortality at $24 \mathrm{~h}$ ), showing no statistical differences between them but different from the control $(P<0.05)$. However, during the exposure period ( $24 \mathrm{~h}$ ) adults mortality ran- ged from $7.5 \%$ to $100 \%$ with significant difference between the samples $(P<0.05)$ where H. gardnerianum, L. azorica and J. brevifolia revealed a mortality rate higher than $97.5 \%$. After the recovery period (after $48 \mathrm{~h}$ from the beginning of the assessment), the mortality ranged from $10 \%$ to $100 \%(P<0.05)$. In adults, the mortality registered at $24 \mathrm{~h}$ was significantly lower than the one observed after the recovery period in $P$. undulatum (leaves) $(P<0.05)$, and $P$. cattleianum (fruits) $(P<0.05)$.

\subsection{Dose-response}

The three essential oils that showed the highest molluscicidal activity against both juveniles and adult stages of $R$. peregra at a concentration of $100 \mathrm{ppm}$ were selected to be tested at lower concentrations in order to determine their respective LC values. $\chi^{2}$ values were not significant $(P>0.05)$, for any essential oil, indicating that the data fit the assumptions of the Probit model. Slopes of the Probit regression lines observed for the concentration-mortality curves are significant among essential oils. The essential oils toxicity was dose dependent against two stages of $R$. peregra (Table 2).

\subsection{Laurus azorica}

presents the lowest slope (3.6) and $H$. gardnerianum the highest one (10.5) for adult snails. The $\mathrm{LC}_{50}$ values calculated for the essential oils, at end of recuperation period, ranged from 45.3 to $54.6 \mathrm{ppm}$. Based on the nonoverlap of $95 \%$ confidence limits of the $\mathrm{LC}_{50}$, these essentials oils were grouped in two classes, the first

Table 2

Estimated $\mathrm{LC}_{50}$ concentrations of essential oils Azorean plants, against juveniles and adults of Radix peregra.

\begin{tabular}{|c|c|c|c|c|c|c|c|c|}
\hline \multirow[t]{2}{*}{ Essential oils } & \multirow[t]{2}{*}{ Plant part } & \multirow[t]{2}{*}{$n^{\mathrm{A}}$} & \multirow[t]{2}{*}{ Concentration interval (ppm) } & \multirow[t]{2}{*}{$\mathrm{LC}_{50}(\mathrm{ppm})$} & \multicolumn{2}{|c|}{ Limits $^{B}$} & \multirow[t]{2}{*}{ Slope value } & \multirow[t]{2}{*}{$H^{\mathrm{C}}$} \\
\hline & & & & & $\mathrm{LCL}$ & UCL & & \\
\hline \multicolumn{9}{|l|}{ Juveniles } \\
\hline Hedychium gardnerianum & Leaves & 40 & $20 ; 30 ; 45 ; 60$ & $44.6^{\mathrm{a}}$ & 40.3 & 51.9 & $4.40 \pm 0.64^{\mathrm{b}}$ & 0.92 \\
\hline Juniperus brevifolia & Leaves & 40 & $10 ; 20 ; 30 ; 40$ & $27.9^{\mathrm{b}}$ & 26.8 & 28.8 & $13.5 \pm 1.15^{a}$ & 0.93 \\
\hline Laurus azorica & Leaves & 40 & $10 ; 20 ; 40 ; 60$ & $15.4^{\mathrm{c}}$ & 13.9 & 16.8 & $3.30 \pm 0.28^{\mathrm{b}}$ & 1.37 \\
\hline \multicolumn{9}{|l|}{ Adults } \\
\hline Hedychium gardnerianum & Leaves & 40 & $30 ; 40 ; 60 ; 70$ & $45.3^{\mathrm{b}}$ & 43.5 & 47.2 & $10.5 \pm 0.77^{\mathrm{a}}$ & 1.68 \\
\hline Juniperus brevifolia & Leaves & 40 & $30 ; 40 ; 60 ; 70$ & $54.6^{\mathrm{a}}$ & 51.5 & 57.7 & $6.50 \pm 0.79^{b}$ & 0.28 \\
\hline Laurus azorica & Leaves & 40 & $30 ; 40 ; 60 ; 70$ & $52.2^{\mathrm{a}}$ & 47.2 & 60.9 & $3.60 \pm 0.62^{c}$ & 1.34 \\
\hline
\end{tabular}

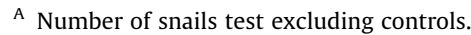

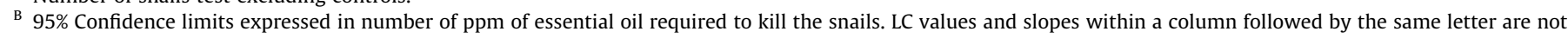
significantly different based on nonoverlapping $95 \% \mathrm{CL}$.

C $H$, heterogeneity factor $\left(\chi^{2}: d f\right)$. 
T. Teixeira et al./Chemosphere 87 (2012) 1-6

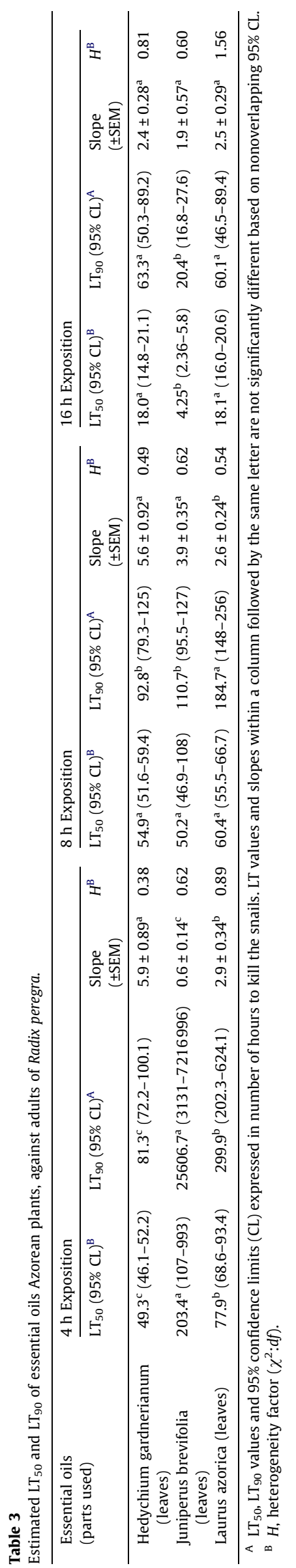

includes $H$. gardnerianum (45.3 ppm of $\mathrm{LC}_{50}$ ) and the second includes $L$. azorica and J. brevifolia (52.2 and $54.6 \mathrm{ppm}$, respectively).

For juveniles snails, $L$. azorica presents the lowest $\mathrm{LC}_{50}$ value (15.4 ppm) which is followed with the lowest slope (3.3). On the other hand, J. brevifolia has the highest slope (13.5) and and $H$. gardnerianum the highest $\mathrm{LC}_{50}(44.6 \mathrm{ppm})$. The slopes were all statistically different.

\subsection{Time-response}

The estimated lethal time $\left(\mathrm{LT}_{50}\right)$ for essential oil samples ranged from 4.3 to $203.2 \mathrm{~h}$ in the three stipulated times ( 4,8 and $16 \mathrm{~h}$ ) (Table 3 ). Probit regression parameters for the time-mortality data indicated the model was valid for all samples. Slope estimated for all of the Probit regression lines were significantly different and ranged from 0.6 to 5.9 . Based on the nonoverlap of $95 \%$ confidence limits, significant differences were established among $\mathrm{LT}_{50}$ values. These differences occur in a different way in the three times observed. At $4 \mathrm{~h}$ expososure $H$. gardnerianum shows the lowest $\mathrm{LT}_{50}(49.3 \mathrm{~h})$. At 8 and $16 \mathrm{~h}$ exposition J. brevifolia presents the lower $\mathrm{LT}_{50}$ (50.2 and $4.3 \mathrm{~h}$, respectively).

\subsection{Ovicidal effects}

The egg hatch rate ranged from $4.2 \%$ to $97.2 \%$, for $P$. undulatum (flowers) and ethanol $5 \%(v / v)$, respectively, with significant differences among treatments $(P<0.05)$. Based on the ovicidal activity of essential oils at $100 \mathrm{ppm}$, the results were classified into two different groups. P. undulatum flowers (4.2\% of eclosions), leaves of H. gardnerianum (4.9\%), L. azorica (7.4\%) and J. brevifolia (17.7\%) exhibit high activity and showed no significant differences between them. The second group, with a reduced or much reduced activity, was formed by fruits of $P$. cattleianum (89.2\%) and leaves of $P$. undulatum (55.7\%) (Table 4).

\section{Discussion}

Our observations on the field revealed that in São Miguel Island the density of $G$. truncatula decreases drastically, when compared with data from Martins (1991). This circumstance may be due to veterinary programs implemented in the last two decades that aiming to control the helminthiasis in the island. Concomitantly to a reduction of the population density of this snail, there is an increase in $R$. peregra population density, in the same places where $G$. truncatula was previously found. This phenomenon could be due to an opportunistic recovery of other molluskan species (e.g. $R$. peregra) as a consequence of a massive use of synthetic molluscicides (Godan, 1983; Agarwal and Singh, 1988).

The decrease in the average of cattle infection rate, recorded in 2009 , could be associated with changes in population density of these two Lymnaeidae species in the island, since the prevalence of infection in snails depends on the possibilities of a natural encounter between snails and trematodes. However, the ability to parasitize different Lymnaeidae species and the high density of an alternative intermediate host might contribute to sustain the larval development of this trematode (Rondelaud, 1993; Dreyfuss et al., 2000). This unspecificity of $F$. hepatica is well documented in the work of Correa et al. (2010), where 26 lymnaeid species, including $R$. peregra, are referred as natural or experimentally infected with this trematode. Even in Ireland, where G. truncatula was the only recorded intermediate host of $F$. hepatica, the evidence of infection in $R$. peregra was also observed by Relf et al. (2009), helping to explain the presence of infection in animals grazing in habitats where G. truncatula is absent. 
Table 4

Percentage of hatching eggs of Radix peregra when exposed for $24 \mathrm{~h}$ to $100 \mathrm{ppm}$ of essentials oils from five Azores plants.

\begin{tabular}{|c|c|c|c|}
\hline Essential oils (parts used) & & $n^{\mathrm{A}}$ & $\%$ Of hatching $( \pm \text { SEM })^{\mathrm{B}}$ \\
\hline \multirow[t]{2}{*}{ Control } & Untreated & 106 & $97.0 \pm 2.1^{\mathrm{a}}$ \\
\hline & Ethanol & 111 & $97.1 \pm 0.4^{\mathrm{ab}}$ \\
\hline \multirow[t]{2}{*}{ Endemic } & Juniperus brevifolia (leaves) & 110 & $17.7 \pm 8.5^{\mathrm{d}}$ \\
\hline & Laurus azorica (leaves) & 119 & $7.40 \pm 5.4^{\mathrm{d}}$ \\
\hline \multirow[t]{4}{*}{ Introduced } & Hedychium gardnerianum (leaves) & 107 & $4.90 \pm 1.0^{\mathrm{d}}$ \\
\hline & Pittosporum undulatum (flowers) & 110 & $4.20 \pm 2.5^{\mathrm{d}}$ \\
\hline & Pittosporum undulatum (leaves) & 108 & $55.60 \pm 12.7^{c}$ \\
\hline & Psidium cattleianum (fruits) & 105 & $89.2 \pm 3.0^{\mathrm{b}}$ \\
\hline
\end{tabular}

\footnotetext{
A Number of eggs test.

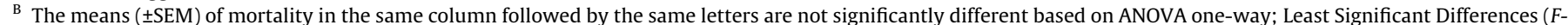
test $=47.586, d f=23)$.
}

The molluscicidal activity of the essential oils from Azorean endemic and introduced plants against $R$. peregra was established in the present work. In previous studies, Mendonça et al. (1993) demonstrated that the aqueous and organic extract of $H$. gardnerianum and $P$. undulatum also has molluscicidal activity against G. truncatula. Furthermore, Warren and Peters (1968) verified that Schistosome cercariae is killed by a substance released from the stems of $H$. coronarium.

Our results indicate that from the six essential oils tested, only $H$. gardnerianum, L. azorica and J. brevifolia are potential source of botanical molluscicides, with toxicity $\mathrm{LC}_{50}$ being less than $55 \mathrm{ppm}$ against juveniles and adults $R$. peregra. These values are, according to Singh et al. (1996b), in the range of high molluscicidal activity. On the other hand, $P$. cattleianum (fruits) and $P$. undulatum (flowers and leaves) showed molluscicidal activity against juveniles at a concentration of $100 \mathrm{ppm}$. For the same concentration, the essential oils from leaves of $H$. gardnerianum, $L$. azorica and $J$. brevifolia and flowers of $P$. undulatum were able to inhibit egg masses hatching.

Toxic effects of H. gardnerianum, L. azorica and J. brevifolia essential oils are time and dose dependent, as it is evidenced from regression between exposure period and $\mathrm{LT}_{50}$ of different treatments. The time dependent toxic effect of plant products may be either due to the uptake of the active moiety, which progressively increases the internal dose and the biologically active dose, or the active compounds metabolized by snails into a new substance with higher toxicity, as it was suggested by Kumar and Singh (2006).

According to Isman (2000), some essential oils have a broad spectrum of biological activities, and their action is due to the compound (s) that occurs in greater quantity in the extract and/or to a synergistic effect between compounds. The identity of the active principles of J. brevifolia, L. azorica, and H. gardnerianum was previously reported, and according to Silva et al. (2000), Pedro et al. (2001) and Medeiros et al. (2003), the monoterpene fraction predominates in the three oils, being $\alpha$-pinene the main constituent of $H$. gardnerianum and $L$. azorica and limonene of $J$. brevifolia. Molluscicidal activity of these two compounds, $\alpha$-pinene and limonene, was described by Lahlou (2004), as well as differences in bioactivity between the enantiomers, thus enabling different modes of action of molluscicides may conceivably be a multicomponent process, affecting more than one system. One of the systems studied by Jaiswal et al. (2008) and Kumar et al. (2009) is the effect of some natural compounds on various enzyme activities, essential for the physiological functioning of mollusks.

In conclusion, this is the first evaluation study of essential oils from Azorean plants against the snail $R$. peregra, a potential alternative intermediate host of $F$. hepatica in natural habitats. Further studies are required to determine the mode-of-action of these essential oil products and the damage they cause to the snail's tissues and the side effects that may exist for the wildlife that surrounds them, through semi-field trials.

\section{Acknowledgments}

We would like to thank José Manuel Viveiros, from the University of Azores for their generous help and to Luísa Oliveira for her invaluable field collaboration. This research was financially supported by Fundação Gaspar Frutuoso and Direcção Regional da Juventude Emprego e Formação Profissional.

\section{References}

Abbot, W.S., 1925. A method of computing the effectiveness of an insecticide. J. Econ. Entomol. 18, 265-267.

Adenusi, A., Odaibo, A., 2008. Laboratory assessment of molluscicidal activity of crude aqueous and ethanolic extracs of Dalbergia sissoo plant parts against Biomphalaria pfeifferi. Travel Med. Infect. Dis. 6, 219-227.

Agarwal, R.A., Singh, D.K., 1988. Harmful gastropods and their control. Acta Hydrochim. Hydrobiol. 16 (2), 113-138.

Backhuys, W., 1975. Land and freshwater molluscs of the Azores. Backhuys \& Meesters, Amsterdam. pp. 350

Bargues, M.D., Artigas, P., Mera y Sierra, R.L., Pointier, J.P., Mas-Coma, S., 2007. Characterisation of Lymnaea cubensis, L. Viatrix and L. neotropica n. sp., the main vectors of Fasciola hepatica in Latin America, by analysis of their ribosomal and mitochondrial DNA. Ann. Trop. Med. Parasitol. 101 (7), 621-641.

Correa, A.C., Escobar, J.S., Durand, P., Renaud, F., David, P., Jarne, P., Pointier, J.-P., Hurtrez-Boussès, S., 2010. Bridging gaps in the molecular phylogeny of the Lymnaeidae (Gastropoda: Pulmonata), vectors of Fascioliasis. BMC Evol. Biol. 10, 381.

Cruz-Mendoza, I., Figueroa, A.J., Correa, D., Ramos-Martínez, E., Lecumberri-López, J., Quiroz-Romero, H., 2004. Dynamics of Fasciola hepatica infection in two species of snails in a rural locality of Mexico. Vet. Parasitol. 121, 87-93.

Cunha, R.T., 1993. Notes on predation of Lymnaea truncatula (Müller, 1774) by the endemic Azorean Zonitid Oxychilus (Drouetia) atlanticus (Morelet \& Drouët, 1857). Bol. Mus. Mun. Funchal. 2, 285-296.

Dreyfuss, G., Vignoles, P., Rondelaud, D., 2000. Variability of Fasciola hepatica infection in Lymnaea ovata in relation to snail population and snail age. Parasitol. Res. 86, 69-73.

El-Kamali, H.H., El-Nour, R.O., Khalid, S.A., 2010. Molluscicidal activity of the essential oils of Cymbopogon nervatus Leaves and Boswellia papyrifera Resins. Curr. Res. J. Biol. Sci. 2 (2), 139-142.

Finney, D.J., 1971. Probit Analysis, third ed. Cambridge University Press, New York

Furtado, R.M.M., Cunha, R.T., 2002. Fasciolose bovina no matadouro frigorífico e industrial de Ponta Delgada, São Miguel (Açores): Actualização de taxas de infestação. Açoreana 9 (4), 331-341.

Godan, D., 1983. Pest Slugs and Snails, Biology and Control (Translated by Shelia Gruber). Springer Verlog, Berlin. pp. 191-215.

Isman, M.B., 2000. Plant essential oils for pest and disease management. Crop. Protect. 19, 603-608.

Jaiswal, P., Sing, D.K., 2008. Molluscicidal activity of Carica papaya and Areca catechu against the freshwater snail Lymnaea acuminate. Vet. Parasitol. 152, 264-270.

Jaiswal, P., Singh, V.K., Singh, D.K., 2008. Enzyme inhibition by molluscicidal component of Areca catechu and Carica papaya in the nervous tissue of vector snail Lymnaea acuminata. Pestic. Biochem. Phys. 92, 164-168.

Kumar, P., Singh, D.K., 2006. Molluscicidal activity of Ferula asafetida, Syzygium aromaticum and Carum carvi and their active components against the snails Lymnaea acuminate. Chemosphere 63, 1568-1574.

Kumar, P., Singh, V.K., Singh, D.K., 2009. Kinetics of enzyme inhibition by active molluscicidal agents ferulic acid, umbelliferone, eugenol and limonene in the nervous tissue of snail Lymnaea acuminata. Phytother. Res. 23, 172-177.

Kumar, P., Singh, V.K., Tripathi, C.P.M., Singh, D.K., 2010. Effects of molluscicidal constituents in spices on reproduction in snails. J. Herbs, Spices Med. Plants 16, 24-35.

Lahlou, M., 2004. Essential oils and fragrance compounds: bioactivity and mechanisms of action. Flavour Frag. J. 19, 159-165. 
Lahlou, M., Berrada, R., 2001. Potential of essential oils in schistosomiasis control in Morocco. Int. J. Aromather 11 (2), 87-96.

Larhsini, M., Sebbane, R., Kchakech, H., Markouk, M., Bekkouche, K., Abbad, A., Khayari, M., Sterner, O., 2010. Screening of some Moroccan plant extracts for molluscicidal activity. Asian J. Exp. Biol. Sci. 1 (4), 964-967.

Lima, W.S., Soares, L.R.M., Barçante, T.A., Guimaraes, M.P., Barçante, J.M.P., 2009. Occurrence of Fasciola hepatica (Linnaeus, 1758) infection in Brazilian cattle of Minas Gerais. Brazil Rev. Bras. Parasitol. Vet. 18 (2), 27-30.

Martins, A.M.F., 1991. Distribuição dos moluscos de água doce em São Miguel e na Terceira. Açoreana 7 (2), 257-276.

Medeiros, J.R., Campos, L.B., Mendonça, S.C., Davin, L.B., Lewis, N.G., 2003. Composition and antimicrobial activity of the essential oils from invasive species of the Azores, Hedychium gardnerianum and Pittosporum undulatum. Phytochemistry 64, 561-565.

Mendonça, M.M., 1987. A fasciolose por Fasciola hepatica L., 1758 em S. Miguel (Açores). Contribuição para o estudo das condições ecológicas da sua transmissibilidade. Dissertação para a candidatura à categoria de Investigador Auxiliar. Instituto de Investigação Científica Tropical, Lisboa, pp. 366.

Mendonça, M.M., 1989a. A distribuição geográfica de Lymnaea truncatula Müller 1774 em São Miguel (Açores) Garcia de Orta. Série Zoológica 16 (1-2), 65-76.

Mendonça, M.M., 1989b. Actividade moluscicida de três espécies forísticas de São Miguel. Ensaios preliminares. Garcia de Orta. Série Zoológica 16 (1-2), 91-95.

Mendonça, M.M., Medeiros, J., Barata, M.C., Lima, E., Rauter, A.P., 1993. Evaluation of potential plant molluscicides from the Azores. List of the plant species tested on Lymnaea truncatula. Res. Rev. Parasit. 53 (3-4), 113-116.

Moens, R., 1982. Mecanisme de reinfestation par Lymnaea truncatula Müller (Molusca, Pulmonata) dês terrains propices a la fasciolose. Malacologia 22 (12), 29-34.

Pedro, L.G., Santos, P.A., Silva, J.A., Figueiredo, A.C., Barroso, J.C., Deans, S.G., Looman, A., Scheffer, J.J.C., 2001. Essential oils from Azorean Laurus azorica. Phytochemistry 57 (2), 245-250.

Radwan, M.A., El-Zemity, S.R., Mohamed, S.A., Sherby, S.M., 2008. Potential of some monoterpenoids and their new $N$-methyl carbamate derivatives against Schistosomiasis snail vector, Biomphalaria alexandrina. Ecotox. Environ. Safe. 71, 889-894.
Relf, V., Good, B., McCarthy, E., de Waal, T., 2009. Evidence of Fasciola hepatica infection in Radix peregra and a mollusc of the family Succineidae in Ireland. Vet. Parasitol. 163, 152-155.

Rondelaud, D., 1993. Variabilité interpopulationelle de l'infestation fasciolienne chez le mollusque Lymnaea truncatula Müller Influence du contact préalable de la population avec le parasite. Bull. Soc. Zool. Fr. 118, 185-193.

SAS Institute, 1982. Systat: the system for statistics. Evaston, IL Systat, Inc.

Schall, V.T., de Vasconcellos, M.C., de Souza, C.P., Baptista, D.F., 1998. The molluscicidal activity of crown of christ (Euphorbia splendens var Hislopii) latex on snails acting as intermediate hosts of Schistosoma mansoni and Schistosoma haematobium. Am. J. Trop. Med. Hyg. 58 (1), 7-10.

Silva, J.A., Pedro, L.G., Santos, P.A., Figueiredo, A.C., Barroso, J.C., Tenreiro, R.P. Ribeiro, C.A., Deans, S.G., Looman, A., Scheffer, J.J.C., 2000. Essential oils from seven populations of Juniperus brevifolia (Seub.) Antoine, an endemic species of the Azores. Flavour Frag. J. 15, 31-39.

Silva, T.M.S., Camara, C.A., Agra, M.D.F., Carvalho, M.G.D., Frana, M.T., Brandoline S.V.P.B., Paschoal, L.D.S., Braz-Filho, R., 2006. Molluscicidal activity of Solanum species of the Northeast of Brazil on Biomphalaria glabrata. Fitoterapia 77, 449452.

Singh, A., Singh, S.K., 2005. Molluscicidal evaluation of three common plants from India. Fitoterapia 76, 747-751.

Singh, A.N., Ahmed, A.H., Sinkkonen, J., Ovcharenko, V., Pihlaja, K., 2006. Molluscicidal activity and new flavonoids from Egyptian Iris germanica L (var. alba). Z Naturforsch C 61 (1-2), 57-63.

Singh, K., Singh, A., Singh, D.K., 1996a. Molluscicidal activity of neem (Azadirachta indica A Juss). J. Ethnopharmacol. 52, 35-40.

Singh, A., Singh, D.K., Mishra, T.N., Agarwal, R.A., 1996b. Molluscicide of plant origin Biol. Agric. Hortic. 13, 205-252.

SPSS, Inc., 2006. SPSS Base 15.0 for Windows User's Guide. SPSS Inc, Chicago, IL.

Upadhyay, A., Singh, D.K., 2011. Molluscicidal activity of Sapindus mukorossi and Terminalia chebula against the freshwater snail Lymnaea acuminate. Chemosphere 83 (4), 468-474.

Warren, K.S., Peters, P.A., 1968. Cercariae of Schistosoma mansoni and plantsattempt to penetrate Phaseolus vulgaris and Hedychium coronarium produces a cercaricide. Nature 217, 647-648 (London). 